\title{
Pengaruh Media Musik Terhadap Keterampilan Menulis Cerpen pada Siswa Kelas X SMA Negeri 3 Bengkayang
}

\author{
Endang ${ }^{1}$, Susan Neni Triani, ${ }^{2}$ Zulfahita $^{3}$ \\ STKIP Singkawang, Singkawang, Indonesia \\ endang.cute78@yahoo.com ${ }^{1}$, susannenitriani@gmail.com ${ }^{2}$, zulfahita@ $@$ yahoo.com $^{3}$
}

\section{Keywords :}

Media musik, keterampilan menulis, cerpen.

\begin{abstract}
Penelitian ini bertujuan untuk:1) untuk mengetahui keterampilan menulis cerpen siswa sebelum menggunakan media musik 2) untuk mengetahui keterampilan menulis cerpen siswa setelah menggunakan media musik 3) untuk mengetahui apakah terdapat pengaruh keterampilan menulis cerpen siswa dengan menggunakan media musik. Populasi penelitian ini adalah semua siswa kelas X SMA Negeri 3 Bengkayang. Sampel Penelitian ini adalah kelas XA dengan jumlah 37 orang. Penelitian ini merupakan penelitian eksperimen yang meliputi pretest, treatment, dan posttest. Metode yang digunakan adalah eksperimen dengan bentuk one group pretest dan posttestdesign. Adapun data yang diambil dalam penelitian ini adalah melalui tes. Sebelum instrumen digunakan terlebih dahulu diuji validitasnya dengan ahli. Untuk instrumen tes sudah memenuhi kriteria validitas isi, reliabilitas, tingkat kesukaran dan daya pembeda soal. Teknik analisis data yang digunakan dalam penelitian ini ada dua yaitu dengan menggunakan rumus rata-rata ( Mean) dan yang kedua menggunakan rumus regresi linier. Berdasarkan analisis data, dapat disimpulkan bahwa rata-rata hasil pretest dan posttest siswa kelas $X A$ SMA Negeri 3 Bengkayang menggunakan media musik mengalami peningkatan dengan nilai pretest 44,05 dan nilai posttest 75,67 dengan kategori baik. Jadi pengaruh media musik terhadap keterampilan menulis cerpen pada siswa kelas X SMA Negeri 3 bengkayang sebesar 3,35 dengan kategori tinggi, hal ini dibuktikan dengan metode effect size.
\end{abstract}

\section{INTRODUCTION}

Pada dasarnya proses belajar mengajar adalah interaksi antara manusia, sumber daya, dan lingkungannya. Proses belajar mengajar merupakan proses yang tersusun secara teratur, yang dapat mengubah kemampuan peserta didik dari suatu tingkatan ke tingkatan yang lain yang lebih baik. Hasil belajar mengajar dapat dicapai secara maksimal apabila komponen-komponen yang berinteraksi dapat berfungsi secara optimal, sehingga perlu senantiasa diupayakan terciptanya situasi kelas yang memungkinkan berlakunya hal tersebut. 
Pengajaran bahasa dan sastra disekolah diberikan empat jenis keterampilan berbahasa. Keempat keterampilan bahasa tersebut yaitu menyimak, berbicara, membaca, dan menulis. Keempat keterampilan tersebut saling berkaitan antara satu dengan yang lain. Menyimak dan berbicara merupakan kegiatan komunikasi dua arah yang langsung. Menyimak bersifat reseptif, sedangkan berbicara bersifat produktif. Membaca dan menulis merupakan aktivitas berbahasa ragam tulis. Menulis adalah kegiatan berbahasa yang bersifat produktif, sedangkan membaca adalah kegiatan yang bersifat reseptif.

Keterampilan menulis merupakan satu diantara dari bentuk keterampilan berbahasa yang sangat penting bagi siswa karena keterampilan menulis adalah kemampuan menuangkan buah fikiran ke dalam bahasa tulis melalui kalimat-kalimat yang dirangkai secara utuh, lengkap, dan jelas sehingga buah pikiran tersebut dapat dikomunikasikan kepada pembaca.Menulis merupakan kegiatan yang sangat sulit dan menjadi suatu beban, karena menulis harus dapat menyusun kosakata yang baik dan harus memiliki imajinasi yang tinggi untuk mengungkapkan pikiran dan perasaannya ke dalam sebuah tulisan. Satu diantarafaktor yang dapat meningkatkan keterampilan menulis cerpen adalah penggunaanmedia yang mendukung.Menulis cerpen merupakan satu diantara kompetensi yang harus dikuasai oleh siswa. Hal tersebut sesuai dengan kurikulum tingkat satuan pendidikan (KTSP) pada standar kompetensi (SK) nomor 16 yaitu mengungkapkan pengalaman diri sendiri dan orang lain ke dalam cerpen. Adapun kompetensi dasar (KD) nomor 16.1 adalah menulis karangan berdasarkan kehidupan diri sendiri dalam cerpen (pelaku, peristiwa, latar). Kompetensi ini akan disampaikan pada siswa kelas X A semester II SMA Negeri 3 Bengkayang.

Alasan penulis memilih keterampilan menulis karena, keterampilan menulis pada sekolah tersebut masih rendah, kurangnya minat siswa dalam menulis cerpen, masih ditemukan ketidaktepatan pemilihan kata dan penggunaan gaya bahasa dalam penulis cerpen siswa, serta guru jarang mengguna media pada saat pembelajaran menulis.

Cerpen yaitu prosa yang menceritakan salah satu segi saja peristiwa yang dialami pelakunya. Menurut Aminuddin ( 2014:134) pengajaran sastra mencakup tiga genre, yakni prosa fiksi, puisi, dan drama. Dari ketiga kompetensi tersebut, yang menjadi titik konsentrasi dalam penelitian ini adalah proses kreatif sastra atau pendidikan kreatif sastra yang mencoba membelajarkan peserta didik untuk mau dan mampu menulis karya sastra. Sebagai satu diantara genre sastra, cerpen, selain mengandung nilai-nilai kehidupan, sosialpsikologis, juga mengandung nilai kesejarahan. Oleh sebab itu guru harus meyakinkan siswa bahwa pengajaran sastra tidak hanya menawarkan hiburan sesaat, tetapi juga akan memberi berbagai manfaat bagi siswa.

Pada kelas yang diteliti yang terjadi adalah siswa mengalami kesulitan menuangkan fikiran dan perasaannya dalam bentuk cerpen. Kesulitan yang dihadapi siswa ditandai dengan beberapa hal seperti, kesulitan menemukan ide, menemukan kata pertama dalam menulis cerpen, mengembangkan ide menjadi cerpen karena minimnya penguasaan kosa kata dalam menulis cerpen, karena tidak terbiasa mengemukan perasaan, pemikiran, dan imajinasi.

Setelah penulis melakukan wawancara di SMA Negeri 3 Bengkayang, dapat diketahui bahwa hasil belajar siswa dalam menulis cerpen masih sangat rendah dari KKM yang diharapkan. Nilai menulis cerpen siswa khususnya kelas X A masih tergolong rendah dan belum mencapai ketuntasan. Adapun kriteria Ketuntasan Minimal (KKM) yang ditentukan yaitu 67, siswa yang memperoleh nilai 67 hanya berjumlah 20 orang dari 37 siswa. Artinya persentase siswa yang tuntas hanya 37,04\%, sedangkan siswa yang tidak tuntas $62,96 \%$.

Rendahnya kemampuan siswa dalam menulis cerpen tersebut disebabkan kurang efektifnya pembelajaran yang diciptakan guru. Guru kurang melakukan inovasi dalam memilih media pembelajaran. Pembelajaran dalam materi menulis terlalu didominasi oleh guru. Hal ini menyebabkan kurangnya interaksi antara sesama siswa dan guru. Belajar yang diciptakan guru di dalam kelas hanya 
sebatas memberikan informasi. Siswa kurang mendapat kesempatan untuk melakukan konstruksi pengetahuan dan melakukan pengembangan pengetahuan itu menjadi sebuah produk pengetahuan baru.

Pembelajaran menulis cerpen dapat terjadi dengan efektif jika guru dapat menerapkan media pembelajaran yang dapat memberikan peluang kepada siswa untuk lebih aktif, kreatif, dan inovatif. Media tersebut diharapkan dapat membuat siswa mempunyai keyakinan bahwa dirinya mampu belajar dengan memanfaatkan potensinya secara maksimal.Media yang dapat meningkatkan pembelajaran menulis cerpen adalah dengan menggunakan media musik. Musik adalah suara yang disusun demikian rupa sehingga mengandung irama, lagu, dan keharmonisan terutama suara yang dihasilkan dari alatalat yang dapat menghasilkan irama. Menurut Campbell (2002:2) musik lebih dari segalanya. Sedangkan menurut Suyadi (2014:131) musik dapat menjadi sarana untuk meningkatkan kecerdasan seseorang karena dengan musik pesan dapat ditangkap lebih dalam, belajar lebih tahan lama, bekerja lebih semangat, pikiran selalu segar (fres), dan hati selalu riang. Tentu, suasana yang demikian akan sangat menunjang kesuksesan seseorang.

Alasan penulis memilih media musik karena, dengan menggunakan media musik diharapkan keterampilan menulis cerpen siswa dapat meningkat, menghilangkan kejenuhan siswa,menarik perhatian siswa, menciptakan suasana belajar yang menyenangkan karena musik ini memberikan alunan irama yang berbeda sehingga membangkitkan semangat siswa dalam menulis cerpen dan siswa akan berusaha untuk mendapatkan hasil yang lebih baik.

Penulis memilih siswa kelas X SMA Negeri 3 Bengkayang tahun pelajaran 2016/2017 sebagai sampel penelitian karena SMA Negeri 3 Bengkayang tahun pelajaran 2016/2017 belum pernah diteliti oleh penulis lain, keterampilan menulis cerpen siswa masih sangat rendah, tidak ada minat siswa untuk menulis cerpen dikarenakan kurangnya buku yang berhubungan dengan cerpen di sekolah tersebut serta penulis dapat membantu guru Bahasa Indonesia meningkatkan keterampilan siswa dalam menulis khususnya menulis cerpen.

\section{METHOD}

Sugiyono (2014:2) menyatakan metode penelitian pada dasarnya merupakan cara ilmiah untuk mendapatkan data dengan tujuan dan kegunaan tertentu. Sedangkan menurut Nawawi (2012:65) metode pada dasarnya berarti cara yang dipergunakan untuk mencapai tujuan.Demikian pula menurut Trianto (2011:194) mengungkapkan metode penelitian berhubungan erat dengan prosedur, teknik, alat, serta desain penelitian yang dipilih. Jadi metode penelitian adalah cara yang digunakan untuk mencapai tujuan tertentu yang berhubungan dengan prosedur, teknik, alat, serta desain penelitian yang dipilih. Prosedur, teknik, serta alat yang digunakan dalam penelitian harus cocok pula dengan metode penelitian yang ditetapkan.

Metode yang digunakan pada penelitian ini adalah metode eksperimen. Menurut Nawawi (2012: 88) metode eksperimen adalah prosedur penelitian yang dilakukan untuk mengungkapkan hubungan sebab akibat dua variabel atau lebih, dengan mengendalikan pengaruh variabel yang lain. Menurut Trianto (2011:203) penelitian eksperimen dapat didefinisikan sebagai metode sistematis guna membangun hubungan yang mengandung fenomena sebab akibat.

Bentuk penelitian yang digunakan dalam penelitian ini berbentuk one group pretest dan posttestdesign. Menurut Sugiyono (2013:110) pada desain ini terdapat pretest, sebelum diberi perlakuan. Dengan demikian hasil perlakuan dapat diketahui lebih akurat, karena dapat membandingkan dengan keadaan sebelum diberi perlakuan

Desain penelitian yang digunakan dalam penelitian ini adalah pre-experimental designs. Menurut Sugiyono (2013: 111) Desain ini dapat dijelaskan seperti berikut $o_{1}$ adalah nilai pretest (sebelum) $\mathrm{O}_{2}$ adalah nilai posttest (sesudah) pengaruh test terhadap prestasi belajar siswa adalah $\left(\mathrm{O}_{2}-\mathrm{O}_{1}\right)$ 
Menurut Sutrisno (dalam Arikunto, 2013: 159) mendefinisikan variabel sebagai gejala yang bervasiasi misalnya jenis kelamin, karena jenis kelamin mempunyai variasi: laki-laki/perempuan, berat badan, karena ada berat $40 \mathrm{~kg}$, dan sebagainya.Selanjutnya menurut Sugiyono (2013:61) variabel adalah suatu atribut atau sifat atau nilai dari orang, objek atau kegiatan yang mempunyai variasi tertentu yang ditetapkan oleh peneliti untuk dipelajari dan kemudian ditarik kesimpulan. Dalam sebuah penelitian terdiri atas beberapa jenis variabel yaitu variabel bebas (independen), variabel terikat (dependen), variabel moderator, variabel intervening, dan variabel kontrol. Yang menjadi variabel dalam penelitian ini menurut Sugiyono (2013:61) ada dua variabel bebas dan variabel terikat. Variabel bebas merupakan variabel yang dipengaruhi atau yang menjadi sebab perubahannya atau timbulnya variabel dependen. Sedangkan Variabel terikat merupakan variabel yang dipengaruhi atau yang menjadi akibat, karena adanya variabel bebas.

Dari uraian diatas dapat disimpulkan bahwa variabel bebas dalam penelitian ini adalah penggunaan media musik, sedangkan variabel terikatnya adalah peningkatan menulis puisi.

\section{RESULTS AND DISCUSSIONS}

Hasil penelitian ini adalah sebagai berikut. Berdasarkan hasil analisis data pretest dan posttest kelas eksperimen maka dapat dibuat rangkuman sebagai berikut. Rata - rata (mean) pretest 4,40 dan rata rata posttest 7,56. Berdasarkan kategori yang ada maka dapat ditentukan hasil dari pretest termasuk kategori kurang dengan rata-rata 4,40 sedangkan posttest tergolong dalam kategori baik dengan ratarata 7,56 .

Setelah melakukan pengujian hipotesis dengan menggunakan chi-kuadrat data yang diuji dalah data pretest dan posttest pada kelas eksperimen. Dalam perhitungan dengan rumus tersebut, apabila indeks yang dihasilkan signifikan lebih kecil 0,05 maka data dala penelitian ini berdistribusi normal. Analisis data menggunkan perhitungan manual menghasilkan indeks yang dapat menunjukan sebaran berdistribusi normal.

Dari data uji normalitas data pretest kelas eksperimen sebesar 0,2779 lebih kecil dari 2,85. Sedangkan uji normalitas data posttest kelas eksperimen diperoleh hasil sebesar -71,8701 lebih kecil dari 2,85. Oleh karena seluruh perhitungan menghasilkan hasil lebih kecil dari 2,85 maka dapat disimpulkan data yang digunakan dalam penelitian ini berdistribusi normal.

Hasil uji hipotesis diketahui bahwa nilai Thitung lebih besar dari pada Ttabel, yaitu 16,8375 maka Ha diterima dan Ho ditolak artinya terdapat pengaruh media musik terhadapa hasil belajar menulis cerpen pada siswa SMA Negeri 3 Bengkayang .

Berdasarkan hasil penelitian nilai rata-rata posttest kelas eksperimen lebih tinggi dibandingkan ratarata nilai pretest. Perbedaan hasil belajar siswa tersebut diikuti pula dengan adanya perbedaan yang ditimbulkan oleh masing-masing model terhadap hasil belajar siswa. Siswa yang diberi perlakuan menggunakan media musik mendapatkan konstribusi yang lebih baik dibandingkan siswa yang diberi perlakuan tidak menggunakan media musik. Dari hasil pengujian hipotesis menggunakan uji t dengan $\alpha=0,05$ diperoleh bahwa nilai $T_{\text {hitung }}$ lebih besar dari pada $T_{\text {tabel }}$, yaitu 16,8375> 3,694 diketahui bahwa Ha diterima dan Ho ditolak.

a. Untuk menjawab sub masalah satu dan dua dapat dilihat dari mean skor pretest dan posttest sebagai berikut.

Perbedaan hasil mean pretest dan posttest menunjukan terjadi peningkatan hasil belajar siswa setelah diberi perlakuan, baik itu dari hasil skor maupun nilai. Pada pretest hasil nilai diperoleh mean 44,05 tergolong dalam kategori kurang dan untuk posttest hasil nilai yang diperoleh mean 75,67 tergolong dalam kategori baik. Peningkatan dengan rata-rata skor sebesar 31,62. Dengan 
demikian dapat disimpulkan bahwa pemberian perlakuan dalam penggunaan media musik dalam pembelajaran menulis cerpen secara teori memberikan pengaruh terhadap hasil belajar pada siswa kelas X terutama kelas X A.

b. Untuk menjawab sub masalah tiga, bagaimana pengaruh media musik terhadapat hasil belajar siswa dalam menulis cerpen diuju dengan teknik analisis uji-t. teknik analisi uji-t bertujuan untuk mengetahui perbedaan tingkat prestasi keterampilan menulis pada tahap awal. Hasil perhitungan uji-t kelas eksperimen dapat dilihat pada lampiran sedangkan rangkuman hasil perhitungan uij-t tercantum dalam tabel dibawah ini.

Dari hasil perhitungan diperoleh $\mathrm{T}_{\text {hitung }}$ sebesar 16,8375. Setelah dibandingkan dengan $\mathrm{T}_{\text {tabel }}$ sebesar 3,694 pada taraf signifikansi sebesar 5\% atau 0,05 dan db 36 ternyata $\mathrm{T}_{\text {hitung }}$ lebih besar dari $\mathrm{T}_{t a b e l}$ artinya ada perbedaan yang signifikan pada pretest kelas eksperimen.

Sebagai tahap akhir menguji hipotesis yang ada dalam penelitian ini berdasarkan uji-t yang telah dilakukan maka dapat dijelaskan bahwa:

1) Hipotesis alternatif (Ha) dalam penelitian ini adanya pengaruh media musik terhadapat hasil belajar siswa dalam menulis cerpen. Sedangkan

2) Hipotesis nol (Ho) tidak ada pengaruh media musik terhadap hasil belajar siswa dalam menulis cerpen .

Dengan demikian apabila $\mathrm{T}_{\text {hitung }}$ lebih besar dari $\mathrm{T}_{\text {tabel }}$ dengan taraf yang digunakan yaitu 5\% atau 0,05 dan db sebesar 36 maka Ho ditolak dan Ha diterima. Karena $\mathrm{T}_{\text {hitung }}$ lebih besar dari $\mathrm{T}_{\text {tabel }}$ maka Ho ditolak dan Ha diterima.

c. Untuk mengetahui seberapa besar pengaruh media musik terhadap keterampilan menulis cerpen pada siswa kelas XA oleh karena itu menggunakan teknik Effect size sebagai berikut:

d. Dalam tabel 5.5 dapat diketahui bahwa Effect size adalah 3,35, berdasarkan kriteria Effect size 3,35 terletak pada kriteria Es $>0,8$ maka Effect size dalam kategori tinggi. Karena nilai Effect size berkategori tinggi maka dapat disimpulkan bahwa media musik berpengaruh terhadap keterampilan menulis cerpen pada siswa XA SMA Negeri 3 Bengkayang.

\section{CONCLUSION AND SUGGESTION}

Berdasarkan hasil penelitian yang diperoleh maka masalah umum yang terdapat dalam penelitian ini dapat disimpulkan sebagai berikut.

1. Bahwa hasil belajar siswa dalam menulis cerpen pada siswa kelas X SMAN 3 Bengkayang sebelum menggunakan media musik memiliki perbedaan yang signifikan pada skor pretest, hal ini dilihat pada mean kelas eksperimen pretest sebesar 44,05 dan hasil yang diperoleh dengan data pretest dapat dilihat bahwa mean masih tergolong rendah.

2. Hasil belajar siswa dalam menulis cerpen pada siswa kelas X A SMAN 3 Bengkayang setelah menggunakan media musik terdapat perbedaan yang signifikan pada skor posttest. Hal ini dilihat pada mean kelas eksperimen sebesar 75,67 tergolong dalam kategori baik dan hasil yang diperoleh dari analisis data posttest dapat dilihat mean lebih tinggi dari hasil awal.

3. Dengan diketahuinya ada perbedaan yang signifikan dengan mean hasil belajar siswa maka dalam hal ini pengaruh media musik terhadap hasil belajar menulis cerpen pada kelas X A SMAN 3 Bengkayang dinyatakan berpengaruh hal ini dibuktikan dengan hasil uji-t dengan perhitungan manual dapat dinyatakan hasil belajar siswa dalam menulis cerpen dengan teknik uji-t sederhana adalah $\mathrm{T}_{\text {hitung }}$ lebih besar dari $\mathrm{T}_{\text {tabel }}(16,8375>3,694)$ maka Ho ditolak dan Ha diterima. Jadi dapat disimpulkan bahwa ada pengaruh antara media musik terhadap hasil belajar siswa kelas $\mathrm{X}$ SMA N 3 Bengkayang dalam menulis cerpan. Hal ini dibuktikan dengan uji effect size sebesar 3,35 dengan kategori Es $>0,8$ maka effect size berkategori tinggi. 
Berdasarkan kesimpulan di atas dengan ini peneliti mengajukan beberapa saran sebagai berikut.

1. Untuk sekolah, hasil penelitian ini diharapkan dapat memotivasi sekolah untuk menggunakan media pembelajaran yang baru.

2. Untuk guru, hasil penelitian ini agar guru lebih selektif dalam pemilihan media musik pembelajaran sehingga siswa lebih tertarik belajar bahasa indonesia.

3. Untuk siswa, diharapkan dapat lebih bersemangat untuk meningkatkan hasil belajar dan aktif dalam proses belajar mengajar.

\section{REFERENCES}

Aminuddin. 2014. Pengantar Apresiasi Karya Sastra. Bandung: Sinar Baru Algensindo.

Arikunto, Suharsimi. 2013. Prosedur Penelitian. Jakarta: Rineka Cipta.

Campbell, Don. 2002. Efek Mozart Memanfaatkan Kekuatan Musik untuk Mempertajam Pikiran, Meningkatkan Kreatifitas, dan Menyehatkan Tubuh. Jakarta: Gramedia Pustaka Utama.

Nawawi, Hadari. 2012. Metode Penelitian Bidang Sosial. Pontianak: Gadjah Mada Unipersitas Press.

Sugiyono. 2014. Metode Penelitian Kuantitatif, Kualitatif, dan R \& D. Bandung: Alfabeta.

Suyadi. 2014. Teori Pembelajaran Anak Usia Dini dalam Kajian Neurosains. Bandung: Rosda.

Trianto. 2011. Pengantar penelitian Pendidikan Bagi Pengembangan Profesi Pendidikan dan Tenaga Kependidikan. Jakarta: Kencana. 